\title{
Greed and Grievances: A Discursive Study on the Evolution of the Lumad Struggle in Mindanao, 2010-2019
}

\author{
Jose Mikhail Perez
}

Department of Political Science, University of the Philippines Diliman, the Philippines ${ }^{1}$

\begin{abstract}
Are vertical or horizontal inequalities causing the Lumad struggle in Mindanao? This study attempts to answer whether ethnic or economic causes, or a combination of both, are motivating the key conflict actors in the Lumad struggle to wage long-term wars. Employing the greed and grievances model in analysing conflicts, we hypothesize that the causes of the Lumad struggle stems from ethnic grievances in the onset of conflict but eventually become an issue on economic greed in the duration of conflict over time. Using critical discourse framework, the study generated a dataset of online headlines from news reports from 2010-2019 in order to trace the framing of the Lumad struggle from the Aquino to the Duterte administrations. The results show that shared discursive themes affirm the notion that the nature of the Lumad struggle is an interaction of ethnic grievances and economic greed due to the interrelationships of various conflict actors on the ground such as the Philippine government, Lumad and Moro insurgents, Christian settlers and multinational corporations. Overall, the findings indicate that issues on ethnic grievances and economic greed in the Lumad struggle are interacting with one another due to notable events occurring on both Aquino and Duterte administrations such as the ongoing peace process between the Philippine government, Moro Islamic Liberation Front (MILF) and the Lumad ethnic groups themselves. Nonetheless, these results must be interpreted with caution due to a number of limitations such as the application of the greed and grievances model as an external explanation inferred from the discursive themes emerging from the news headlines and the lack of previous studies detailing the Lumad struggle using the said framework.
\end{abstract}

Keywords: inequalities, ethnic grievances, economic greed, Lumad, Mindanao.

\section{Introduction}

Armed conflicts continue to hamper economic development in Mindanao, the southernmost of the three major island groups in the Philippines. Historically speaking, Mindanao has followed a different a different historical trajectory to the rest of the Philippines due to its early encounters with Islam in the fifteenth century (Majul, 1973). Furthermore, the presence of non-Muslim indigenous peoples' in Mindanao known as the Lumads, have also been struggling to protect their ancestral lands from Western colonialism, Christian settlers and capitalist interests (Alamon, 2017).

The Moros, the collective identity of the indigenous groups in Mindanao who converted to Islam, have waged a more organised insurgency by establishing armed groups such as the Moro Islamic Liberation Front (MILF) and the Moro National Liberation Front (MNLF) in voicing out their grievances against the Philippine government. This leaves the Lumads in a vulnerable position where their struggle is often viewed as a "footnote within a footnote" in traditional Philippine history (Dizon, 2014).

This struggle campaigned by the Lumads, often considered forgotten, is still unexplored due to the lack of literature that explains the dynamics of warfare waged by the various non-Moro tribes to protect their ancestral domain. The plight of the Lumad is rarely discussed in the political science and economics literature as manifested in a few notable researches that attempt to document their struggle (Alamon, 2017; Paluga \& Ragragio, 2016; Paredes, 2013; Rodil, 1993; Tebteba Foundation, 2011). These few studies have focused on the traditions and narratives that describe the Lumad struggle as a "war on extinction" (Alamon, 2017) or a "mountain of difference" (Paredes, 2013). Some have attempted to explain why the displacement of the Lumads from their communities are prevalent due to military aggression campaigned by the Philippine government (Paluga \& Ragragio, 2016). Others have explored the

${ }^{1}$ Correspondent email:jmfperez2014@gmail.com 
interactions of the Lumad with the Moros where the latter has established armed groups aiming to secede from the Philippine state (Rodil, 1993). Also, some of them have focused on the documentation of their traditions such as their legends, stories and poetry (Tebteba Foundation, 2011). Thus, the lack of literature detailing the Lumad conflict as a separate one from their Moro counterparts shows an important gap in the existing literature of the Mindanao conflict.

The Lumad struggle has received less attention in Philippine scholarship due to a variety of factors. One major factor is due to the peaceful nature of Lumads when interacting with outsiders, making them more vulnerable against Western colonisers and Christian settlers in Mindanao (Paredes, 2013). Some groups such as the Higaonons in Misamis Oriental have migrated to the mountains upon the arrival of Western colonisers and Christian settlers (dumagats) in order to escape the dangers brought by these outsiders. This form of resistance is known as ilihan which has been historically practiced even in pre-colonial times (Paluga \& Ragragio, 2016).

However, when provoked by capitalist interests to encroach their ancestral lands, the Lumads fight back in order to protect the rich resources found in their ancestral lands known as yutang kabilin in Cebuano (Alamon, 2017; Rodil, 1993). For instance, Paluga and Ragragio (2016) cited the case of the Manobo communities in the Pantaron mountains that have waged armed confrontations against the Alcantara and Sons' logging operations in their ancestral lands in 1992. This form of resistance is known as pangayaw, where able-bodied men wage a 'tribal war' against their aggressors that leads to violent confrontations and revenge killings if further aggravated (Paluga \& Ragragio, 2016).

As mentioned earlier, another notable factor why the Lumad struggle is understudied is because the Lumads have never formed an organised armed movement against the Philippine government (Alamon, 2017). This forms the basis of political and ethnic grievances of the Lumad against the Philippine government that backs capitalist interests to invade their ancestral lands. These form of deprivation creates horizontal inequalities where the Lumad minorities are systemically discriminated by the Christian majority and Moro groups (Paredes, 2015).

In the duration of the conflict, these grievances are believed to have turned into vertical inequalities where economic disparities are more highlighted upon the introduction of a Torrens land system that favoured land ownership to the Christian migrants and multinational corporations due to the Lumad's lack of knowledge in the newly enacted laws. This form of deprivation has placed most non-Moro ethnic groups at an economic disadvantage in their own homeland due to the expansion of extractive activities such as mining and logging, causing a state-backed war against the Lumads known as "wars on extinction" (Alamon, 2017).

In this article, our goal is to explain whether vertical or horizontal inequalities, or a combination of both, are causing the Lumad struggle in Mindanao to exacerbate over time. Using Collier and Hoeffler (2004) and Keen's (2012) greed and grievances framework on intrastate conflicts, this article seeks to understand and explain the reasons why there is ongoing conflict in Mindanao, particularly in Lumad lands. Specifically, this article aims to contribute to the existing literature on how we understand intrastate conflicts by using the Lumad's struggle as a case study. Furthermore, it also aims to explain the evolution of such conflict and how it fits in the larger picture on the various insurgencies taking place around the world.

This article is divided into several parts. The first part attempts to review the existing literature on wars and conflict in the Philippines and relate it to the ongoing Lumad struggle and how it has evolved over time. Next, we lay out a framework in making a claim that the struggle is caused by either vertical or horizontal inequalities, or a combination of both by using the greed and grievances model interpreted by Collier and Hoeffler (2004) and Keen (2012).

The next part shall explain the method and design that is used in this article. Since the research problem is focused on understanding the framing of ethnic or economic identities in the Lumad struggle, this article has traced the discursive origins of the conflict by looking into the online news headlines regarding the Lumad conflict in MindaNews from 2010-2019 by using Fairclough and Wodak's (1997) critical discourse analysis (CDA). By applying this method, the article suggests that a critical analysis of the online news headlines in the Lumad struggle will provide a clear understanding of the framing of conflict. Finally, the remaining parts of the article will provide a descriptive explanation on the results and a brief discussion of the data collected. A conclusion will then provide a summary of the findings of the study and recommendations for future studies in the Lumad struggle.

\section{Explaining Wars and Conflicts}

The study of wars and conflicts has been of great interest of study from scholars of various disciplines ranging from anthropology, sociology, political science, economics and international relations. Unfortunately, most of them often use confusing words without even defining them. The terms 'conflict', 'internal conflict', 'civil war' and 'violence' are often used interchangeably by various scholars in explaining any form of conflict involving violence between adverse parties.

Throughout the study on the nature and duration of intrastate conflicts, one of the most significant findings is that per capita income is negatively correlated with civil war, whether it be on the onset or duration (Ray \& Esteban, 2017). This argument is borne out of the numerous studies conducted by Collier and Hoeffler (2004) that conflicts 
have economic causes. This was further elaborated by Fearon and Laitin (2003), Reynal-Querol (2002) and Hoeffler (2011) where conflicts are caused by specific economic characteristics such as dependence on primary commodity exports, low average income and slow economic growth.

In order to systematically understand wars and conflicts, Collier and Hoeffler (2004) have defined 'conflict' as an "internal conflict with at least 1,000 combat-related deaths per year where both government forces and an identifiable rebel organization must at least suffer 5\% of the fatalities". This definition has been the mainstream argument in explaining civil wars since it has been frequently cited by several international organizations such as the World Bank and the United Nations in guiding their policies to resolve intrastate conflicts (Collier, 2007).

On the other hand, an alternative explanation suggests that horizontal inequalities, which are defined as "inequalities between groups, whether it be ethnic, religious or region", cause a significantly higher probability of onset of conflict in the long run (Stewart, 2000). This alternative argument is based on the numerous studies conducted by Stewart $(2000,2005)$ which has influenced a lot of scholars in explaining that systemic forms of deprivation, exclusion and repression by dominant ethnic groups against minorities have created political grievances that justify rebel movements. This was further elaborated by Aspinall (2007), Østby (2008) and Keen (2012) where the onset of conflicts are caused by political entrepreneurs who utilize local grievances in order to mobilise ethnic groups to resort to violence. Despite the obvious explanations that ethnic differences causes grievances to create conflict, it is still hard to predict if these inequalities will often motivate insurgents to rebel in the long run.

\section{Greed and grievances as conceptual framework}

Are horizontal or vertical inequalities causing the Lumad struggle in Mindanao? The research problem that this article tries to address is to find out whether the presence of more vertical or horizontal inequalities causes a higher incidence of violent conflict in the Lumad struggle. Since most of the scholarship in the Mindanao conflict give emphasis on the ethnic divides between ethnic groups, this study argues that a useful starting point is to understand the onset and evolution of the conflict.

The conceptual framework used in this study is an application of the greed and grievances model to the Lumad struggle in Mindanao (Collier \& Hoeffler, 2004; Keen, 2012). Drawing from Collier and Hoeffler's (2004) and Keen (2012) model, the study argues that the internal conflicts are caused by the interaction horizontal and vertical inequalities in the onset and duration of the Lumad struggle.

As stated by Collier and Hoeffler (2004), vertical inequalities, defined as "inequalities between individuals and households in a society", causes armed groups to act on the basis of their self-interests since the economic benefits tend to outweigh the costs of conflict. The presence of export primary commodities in disputed areas and the profiteering from it by rebel groups tends to prolong the conflict due to the profits gained from war which lead rebels to buy more weapons and finance combatants.

On the other hand, Stewart (2000) argues that horizontal inequalities, defined as "inequalities between groups, whether it be ethnic, religious or region", cause a significantly higher probability of onset of conflict in the long run. The inequalities fostered by the exploitation of natural resources by dominant groups in to ethnic minorities tends to fuel grievances due to the exclusion of other groups to access of such resources.

However, an alternative explanation is posited by Keen (2012) that both horizontal and vertical inequalities interact over time, causing more rebellion and violence in the duration of conflict. Hence, it would be hard to distinguish the two causes of the conflict over time.

One testable hypothesis can be inferred from the discussion above. We can infer that the nature of the Lumad struggle is caused by the interaction of both horizontal and vertical inequalities that transforms conflicts in the longue durée. In this study, therefore, our independent variable is horizontal and vertical inequalities, while our dependent variable is the Lumad struggle in Mindanao. For our analysis, we define specific concepts in order to operationalise the concepts mentioned in the framework earlier. This will be mentioned in the data and methodology part of this article.

\section{Explaining Conflicts in the Philippines}

It is a well-established fact that most conflicts around the world commonly occur in places where development is felt least (Collier, 2007). Based on Collier and Hoeffler's (2004) dataset, 77 out of the 79 conflicts listed from 1960 to 1999 are located in developing countries. For this instance, Collier (2007) argues that most countries that are prone to conflicts are the ones that have slow growth, or worse, stagnation or decline.

Evidence shows that most of these conflicts occur in Asia where wars tend to last longer than in any region. These conflicts tend to happen if dominant ethnic groups often migrate to less developed peripheral regions of country which are often supported by state development projects (Fearon, 2004). For instance, most of these conflicts can be 
observed on the rebellions waged by the Chakma people in Bangladesh, Tamil people in Sri Lanka, Uighur people in China and Moros in the Philippines. From these numerous conflicts, the rebellions in the Philippines tend to last longer due to the armed struggle between the Moro Muslims, Christians and Lumads in the Mindanao. This ongoing conflict is regarded as the one of longest insurgencies in Asia due to its historic and ethnic roots (Uppsala Conflict Data Program, 2019; Yigit, 2018).

From the various ethnic groups in the Mindanao conflict, the Lumads are perceived to be the weakest since they are usually left behind in consultations on peace agreements as manifested in the different agreements between the Muslim groups and the Philippine government such as the Comprehensive Agreement on the Bangsamoro (CAB) in 2014 and the plebiscite for an autonomous Bangsamoro region (BARMM) in 2019. Thus, less attention has been given to the grievances of the Lumad since they have been subjected to forced recruitment by different state and nonstate armed groups, leaving them without an organised armed movement (Coronel-Ferrer, 2013).

In the study of the Mindanao conflict, much attention has been focused on the Moro struggle because they are able to fully mobilise their forces along religious and ethnic lines. Majul (1973) argues that the reason why the Moros have waged successful wars was in Mindanao was because of the ability of the Moro groups to rally on their fellow Muslims by waging war against Spanish colonisers in the name of Islam. For centuries, the Moros have fought against the Western colonisers, Christian settlers from Luzon and Visayas and recently, Philippine government forces in order to reclaim their ancestral domain known as the "Bangsamoro" or "the homeland of the Moros" (Lara \& Champlain, 2010; Quimpo, 2001).

Unfortunately, this is not the case for the Lumads in Mindanao. The Lumads have never formed a coherent armed group to fight against the Philippine government due to their gentle nature where they have migrated to the mountains in order to escape the chaos waged by colonisers and migrants in the lowlands (Tebteba Foundation, 2011). However, despite their gentle nature, this has not stopped them from fighting for their ancestral domain - their primary source of identity. The Lumads have waged their own struggle in the highlands when Spanish and American colonisers have occupied their lands without their permission (Alamon, 2017). Furthermore, the interests of corporations venturing into extractive industries such as mining and agribusiness development have forced the Lumads to set aside their gentle nature and resort into more violent means to voice out their grievances such as joining the armed struggle of the New People's Army (NPA) or by forging alliances with the Moro armed groups such as the Moro Islamic Liberation Front (MILF) in order to highlight their struggle to the Philippine government (Alamon, 2017).

In understanding the Mindanao conflict, the conventional argument proposed by most Filipino scholars is that the armed conflict is only rooted on ethnic divides between Christians and Muslims (e.g. Coronel-Ferrer, 2013; Griffen, 2018; Lara and Champlain, 2009; Majul, 1973; Quimpo, 2001; Wadi, 2008). Furthermore, due to the recent popular framing of the press on the Moro resistance as "jihad", the conflict in Mindanao has always been a "Muslim-Christian conflict". This framing creates a myopic view of the Mindanao conflict as a Moro struggle against the Christian government by disregarding other factors, particularly the role of the Lumads who are also included in a shared vision of a "Bangsamoro" as "all peoples living in a contested territory" (Coronel-Ferrer, 2013).

The reduction on the framing of the Mindanao conflict as predominantly ethno-religious in nature has dominated in the mainstream discourse of Philippine scholarship on the Mindanao issue. An alternative explanation from Coronel-Ferrer (2013) suggests that the Moro resistance is basically a nationalist struggle to free the Muslims in the Philippines and their claimed homeland from Filipino colonialism and oppression. On the other hand, such argument leaves a significant gap in the literature of the Mindanao conflict because it disregards the Lumad's struggle for their own homeland within the proposed Bangsamoro homeland since they are often regarded as second-class citizens primarily through bureaucratic neglect, political domination by the Moros, state favouritism towards the Christian settlers, and legal exclusions pertaining specifically to land (Paredes, 2015). Hence, the legitimate demands of the Lumads have been ignored by the Moros and the national government where the former have regularly resorted to the latter's priorities, including throwing away the Lumad's long struggle for autonomy (Paredes, 2015).

Drawing from the arguments mentioned earlier, most Filipino scholars have delved on the Mindanao issue as an ethno-religious conflict between Muslims and Christians since the Moros have fully asserted their rights to selfdetermination against a dominant Christian state (Coronel-Ferrer, 2012). Additionally, it is notable that most of them have scarcely explained on how the Lumad struggle is situated in the larger Mindanao conflict despite the reality that the various Lumad groups have been asserting their right to their ancestral domain due to the overlapping claims between the Moros and Lumads in some territorial domains (Paredes, 2015; Paluga \& Ragragio, 2016).

Moreover, it seems that there is a lack of a compelling framework in explaining the nature of these conflicts is evident in most of the literature of the Lumad struggle. Most Filipino scholarship is focused on explaining the current dynamics of the Mindanao conflict without establishing the causality and the evolution to why it has endured for a long time. Hence, the greed and grievance model provides a useful tool in understanding the causes of this conflict in 
order to understand the costs and benefits that the Mindanao war creates to the various key actors interacting on the ground.

\section{The Evolution of the Lumad Struggle in Mindanao}

The Lumads are referred to as the indigenous people in Mindanao who have not converted to Islam or Christianity (Alamon, 2017; Paredes, 2015). They have retained their animist beliefs and traditions, in which some historians refer them as 'non-Moro' since they have not converted to Islam like their Moro counterparts (Rodil, 1993). The name Lumad is a collective term derived from the Cebuano word meaning 'indigenous'. Hence, despite their common 'non-Moro' identity, they are still divided in terms of their ethnolinguistic heritages and 'tribal' identities (Paluga \& Ragragio, 2016).

The Lumads are believed to have existed in Mindanao since precolonial times. They have developed a system of protecting their ancestral lands through the concept of pangayaw or 'tribal wars' as the act of attaining justice to reclaim their ancestral lands from outsiders (Tebteba Foundation, 2011).

The onset of the Lumad struggle is a product of the constant encroachment of outsiders to exploit their land. Initially, the Lumads have kept their grievances within themselves due to their peaceful attitude towards outsiders. Whenever there are outsiders who try to exploit their lands, they have taken refuge in the mountains and forests in order to escape discrimination and oppression and seek protection from it. The constant displacement of these various non-Moro tribes has led them to resort to various creative ways of dealing their situation by transforming it as a form of protest and resistance in the lowlands of Mindanao (Paluga \& Ragragio, 2016).

The arrival of Spanish forces in Mindanao have attempted to forcefully annex Lumad and Moro lands as part of their colonial empire. The Spaniards have tried to occupy Mindanao upon their arrival in the sixteenth century but were largely unsuccessful due to the consistent opposition of the Muslim sultanates and various Lumad tribes (Rodil, 1993). Tensions between Lumad tribes and the Spanish forces were documented in the Kagayanon conversion of Lumad lands as Christian settlements in the 1620s and the Caraga revolts in 1631 that aimed to protect the ancestral domain of the Lumads from outsiders (Paredes, 2013). It is in this case that the Spaniards considered the Lumads as 'non-Moros' due to their distinct language and traditions from the Christians and Moro tribes. Since the Spaniards have only categorised Filipinos between Christians and non-Christians, the non-Moro tribes are regarded as 'uncivilised' which further exacerbated their grievances against the Spanish government due to systemic discrimination (Alamon, 2017).

After the Spanish colonial government was defeated in the Spanish-American War, the sultanates of Sulu and Maguindanao, along with the ancestral lands of the Lumads, were annexed by the American colonial government through the signing of the Treaty of Paris in 1898. Upon their arrival, the Americans have considered the Lumads as 'Wild Tribes' where they are forcefully assimilated with the existing colonial government through educational programs and assimilation policies under the American colonial policy of 'benevolent assimilation'. The Lumads have expressed resistance against American control after the creation of Agusan and Bukidnon as 'special provinces' of the 'Wild Tribes'. Inter-communal violence between the Lumad and American colonial forces became prevalent in the early part of the twentieth century. Along with their Moro counterparts, the Lumads believe that the forceful annexation of their ancestral lands to the Philippine colonial government has legitimised their grievances in fighting for autonomy (James, 2018; Rodil, 1993).

In order to quell the Moro and Lumad rebellions in Mindanao, oppressive land laws were institutionalised by both colonial governments. Traditional concepts of land ownership such as communal rights and the notion of ancestral domain where Lumad and Moro groups co-existed peacefully are nullified (Quimpo, 2001). Furthermore, the Americans have used the Torrens land system where these newly institutionalised laws were created in favour of the Christian settlers who have arrived in Mindanao. These were followed by resettlement programs conducted by succeeding administrations after World War II.

The continuous support of these administrations to the Christian migrants in occupying the ancestral lands of the Lumad has led to the evolution of the nature of the struggle as a conflict that concerns economic inequalities. The primary objective of the Philippine government to make Mindanao a 'land of promise' has encouraged Christian settlers to occupy lands in Mindanao through the resettlement programs in the 1950s-1970s (Majul, 1973; Quimpo, 2001). Furthermore, the arrival of multinational corporations, usually owned by the Christian migrants, have exploited the natural resources found in Lumad lands, particularly coffee, timber and other precious minerals. This has exacerbated the conflict where the Lumads are found fighting to secure their land from capitalist interests (Alamon, 2017).

The "capitalist greed" of multinational corporations and the Christian settlers to occupy the lands of the Lumads have led to more skirmishes between the Christian settlers and Lumad communities (Paluga \& Ragragio, 2016). Several clashes were documented on the land conflicts between Tedurays, Maguindanaons and Ilonggo 
Christians in Maguindanao in the 1970s and the Subanens and Christian settlers in Zamboanga in the 1990s. Thus, it can be inferred that the political and ethnic deprivation fostered by the Western colonisers has now led to the interaction of vertical and horizontal inequalities where Lumad tribes have to preserve their land through the use of violent means.

In its long history, the political awakening of the Lumads to unite themselves has only materialised during the Marcos dictatorship despite several attempts in the past. Initially, the term 'Lumad' was used by activists to refer to the non-Moro indigenous people in Mindanao who have suffered from state-sponsored development such as logging, mining, and agribusiness development. In response, the term was adopted by the tribes themselves on June 26, 1986 when an assembly of 15 out of the 18 indigenous tribes in Kidapawan, North Cotabato formally adopted the term as a self-ascribed collective identity distinguishing themselves from the Moro tribes and Christian settlers in Mindanao (Alamon, 2017).

After the EDSA Revolution in 1986, the exploitation of the natural resources in the various provinces in Mindanao has led to what Alamon (2017) calls as 'wars on extinction'. These wars have left the Lumads fighting over control of what is left in their ancestral lands from capitalist interests who are now supported by the Philippine government. These resource wars are documented in the struggles of the Pulangion Manobo in Bukidnon and the Banwaon in Agusan del Sur where mining companies have exploited their land in order to conduct extractive activities (Alamon, 2017).

Furthermore, the recruitment of rebels by state and non-state armed groups has become a prevailing theme in the Lumad struggle where state forces recruit Lumads in paramilitary groups while communist forces in the New Peoples' Army (NPA) recruit them in their armed struggle (Coronel-Ferrer, 2013). The recruitment of Lumad leaders by the NPA has subjected them into extortion activities through the collection of "revolutionary taxes" in resourcerich areas. The policies created by the NPA create a notion that ethnic grievances fuel economic inequalities that worsen the conflict.

The dispossession of the Lumad in their lands by multinational capitalist corporations has forced their leaders to fight for their lands they swore to protect. Recent events in Mindanao also play an important factor in determining the future of the Lumad struggle. The constant clashes between the Philippine government through its paramilitary groups and the NPA have left the Lumads in the middle of a conflict that they never wanted (Coronel-Ferrer, 2013). The burning of Lumad schools being "red-tagged" as "NPA schools" are causing tensions between the Lumads and paramilitary groups who are usually funded by multinational corporations (Paluga \& Ragragio, 2016).

Furthermore, the recent agreement between the Philippine government and the MILF through the creation of a Bangsamoro autonomous region has exacerbated tensions between ethnic groups due to overlapping territorial claims (Paredes, 2015). During the peace talks in the proposed Bangsamoro territory, some Moro leaders want to exploit the resources found in their proposed territory while Lumad leaders want to retain these lands as autonomous regions for the Lumad (Coronel-Ferrer, 2012; Paredes, 2015). This has led to more tensions due to the polarising interests of both ethnic groups.

\section{Method and Data Analysis}

In analyzing the data, the article used Fairclough and Wodak's (1997) critical discourse analysis (CDA) method in analysing the evolution of the Lumad struggle through the framing of discourses on the Lumad conflict in news headlines. The study looked into online news headlines that tackle the Mindanao conflict on MindaNews, a prevalent news website that covers Mindanao issues. The time frame covered in this article only covered two administrations, Benigno Aquino III (2010-2016) and Rodrigo Duterte (2016-2019) due to timing and relevance purposes. Both administrations were successful in establishing peace settlements between the national government and the MILF through the signing of the $\mathrm{CAB}$ in 2014 under the Aquino administration and the conduct of a plebiscite that created a Bangsamoro Autonomous Region (BARMM) in 2019 under the Duterte administration.

For our discursive analysis, the study collected 257 online headlines in MindaNews from 2010-2019 and created a dataset analysing specific keywords on certain headlines that portray the Lumad struggle either depict an issue of or "grievance" or "greed" using the framework of Collier and Hoeffler (2004) in the 'greed' discourse and Ross (2004) in the 'grievance' discourse are used.

Utilizing Fairclough and Wodak's (1997) critical discourse analysis method, the study has affirmed that shared discursive themes affirm the notion that the nature of the Lumad struggle is an interaction of grievances and greed due to the interrelationships of key conflict actors on the ground. Moreover, the findings indicate that issues on grievances and greed in the Lumad struggle are interrelated in the midst of notable events occurring in Mindanao such as the peace process with the Moro groups that may affect the future of the Lumad tribes in the Bangsamoro autonomous region.

Hence, the study has generated a dataset that lists down the headlines related to the Lumad and Moro struggle in order to distinguish both conflicts. The headlines are then classified into three categories: (1) Moro (M); (2) Lumad and (3) Uncertain $(U)$ for unclear headlines. Another important consideration in labelling certain headlines as Moro 
(M) or Lumad (L) is on whether the headline talks about a certain Moro or Lumad tribe in order to distinguish headlines of both conflicts. From the categorised conflicts, we separate the Lumad-related headlines in order to classify them as either a grievance-related (G1) or greed-related (G2) headline. In identifying whether these headlines constitute a greed or grievance headline, a few relevant phrases were considered in depicting 'greed' or 'grievance' using the framework of Collier and Hoeffler (2004) in the 'greed' discourse and Ross (2004) in the 'grievance' discourse. The table below shows an exhaustive list of words used in the article.

Table 1.

Greed, Grievance and Conflict Indicators

Grievance/greed indicators

Grievance or greed related words (resources, peace talks, violence)

Grievance-related words (peace talks, Lumad schools, displacement, violence, Martial Law)

Greed-related words (coffee, mining, logging, land issues, businesses, NPA extortion)
Conflict indicators

Conflict-related words (War, conflict, struggle, violence, killings, peace process)

Words related to the Moro conflict (Moro, Muslims, Maranao, Tausug, Yakan, Maguindanao)

Words related to the Lumad conflict (Lumad, non-Moro indigenous people, T'boli, B'laan, Manobo)

\section{Operationalizing greed and grievance: Horizontal and vertical inequalities}

As mentioned earlier, we refer to horizontal inequalities as "inequalities between groups, whether it be ethnic, religious or regions" (Stewart, 2000). These inequalities are believed to cause a higher probability of the onset of conflict (Osby, 2008). This form of inequality forms the basis of the 'grievance argument' as the primary cause of intrastate wars (Stewart, 2000; Keen, 2012).

We operationalize horizontal inequalities in terms of a one count variable of news headlines that contain at least one of the grievance-related keywords in the Lumad struggle such as peace talks, Lumad schools, displacement, violence and Martial Law.

On the other hand, we refer to vertical inequalities as "inequalities between individuals and households in a society" (Collier, 2000). These inequalities are believed to cause a higher probability of conflicts to endure over time (Collier, 2000; Fearon, 2004). This form of inequality forms the basis of the 'greed argument' as the primary cause of intrastate wars (Collier \& Hoeffler, 2004).

We operationalize vertical inequalities in terms of a one count variable of news headlines that contain at least one of the greed-related keywords in the Lumad struggle such as coffee, mining, logging, land issues, businesses and NPA extortion.

\section{The Moro and Lumad conflicts}

The Moro and Lumad conflicts in Mindanao can be classified in terms of intrastate conflicts as defined by the Uppsala Conflict Data Program (2019). We refer to conflict "as a contested incompatibility that concerns government and/or territory where the use of force between two parties, of which at least one is the government of a state..." (Wallensteen, 2015).

We operationalize conflict in terms of a one count variable of news headlines that contain at least one of the conflict keywords such as war, conflict, struggle, violence, killings and peace process. Furthermore, we then distinguish these conflicts as Moro, Lumad or uncertain in terms of a one count variable that contain at least one of the Moro and Lumad keywords such as Moro, Muslims and the various Moro tribes such as the Maranao, Tausug, Yakan, Maguindanao to name a few in the Moro conflict and Lumad, non-Moro indigenous people and the various Lumad tribes such as T'boli, B'laan, and Manobo to name a few in the Lumad struggle.

\section{Results}

In total, the study has identified and analysed 257 headlines on MindaNews from 2010-2019. Table 2 shows that there are more headlines that cover the Moro struggle over the Lumad struggle. From the 257 headlines, more than $50 \%$ cover the Moro conflict $(56.42 \%)$ while a mere $20.23 \%$ cover the Lumad struggle. 
Table 2.

News Headlines in the Mindanao Conflict

\begin{tabular}{|ccc}
\hline Form of conflict & Frequency & Percentage \\
\hline Moro (M) & 145 & 56.42 \\
Lumad (L) & 52 & 20.23 \\
Uncertain (U) & 20 & 7.78 \\
\hline
\end{tabular}

From the 52 Lumad-related headlines, more than half of these are covered under the Benigno Aquino III administration $(59.62 \%)$ with 31 headlines. Table 3 shows that the predominant issues frequently mentioned are more grievance-based (25 counts) than greed-based (6 counts). Among the top grievance-based issues concerning the Lumads under the Aquino administration are (1) peace talks; (2) violence; and (3) displacement while the top greedbased issues are (1) NPA extortion, (2) businesses, (3) land issues and (4) mining.

The emergence of the 'peace talks' as the most prevalent grievance-based issue can be attributed on the recent peace agreements between the Philippine government and the MILF group. Under the Aquino administration, the Comprehensive Agreement on the Bangsamoro (CAB) was signed in 2014 which affirms Paredes' (2015) argument that the legitimate needs of the Lumads are often ignored, and in some cases deliberately undermined, by the Moros and the national government.

On the other hand, the emergence of the 'NPA extortion' as the most prevalent greed-based issue can be attributed on the recruitment of Lumads by the NPA rebels in order to join their cause for an armed struggle against the Philippine government (Alamon, 2017). The role of the NPA in the Lumad conflict is highlighted upon the CPPNPA's framing of the Lumad identity as a class struggle which makes it conducive for the Lumads to join their rebellion.

Table 3.

Frequency of Lumad-Related Headlines under the Aquino Administration

\begin{tabular}{|ccc|}
\hline Issue (Greed or Grievance) & Frequency & Percentage \\
\hline Peace talks (Grievance) & 14 & 45.16 \\
Violence (Grievance) & 6 & 9.65 \\
Lumad schools (Grievance) & 3 & 9.68 \\
NPA extortion (Greed) & 3 & 6.45 \\
Displacement (Grievance) & 2 & 3.23 \\
Businesses (Greed) & 1 & 3.23 \\
Land issues (Greed) & 1 & 3.23 \\
Mining (Greed) & 1 & 3 \\
\hline
\end{tabular}

On the other hand, only 21 out of the 52 Lumad-related headlines are covered under the Duterte administration (40.39\%). Table 4 shows that the predominant issues frequently mentioned are grievance-based (16 counts) rather than greed-based (5 counts). Among the top grievance-based issues concerning the Lumads under the Duterte administration are (1) violence; (2) peace talks (3) displacement and (4) Martial Law while the top greed-based issues are (1) NPA extortion, (2) businesses, (3) land issues and (4) coffee.

The emergence of the 'violence' as the most prevalent grievance-based issue can be attributed to numerous Lumad killings caused by the Philippine military in "red-tagging" Lumad activists insurgents as "NPA rebels" by burning and militarising their schools and communities. This causes intense displacement among Lumad communities, thus, forcing them to be subjected to cycles of evacuations (Paluga \& Ragragio, 2016). 
Nevertheless, the enduring concern of 'NPA extortion' as the most prevalent greed-based issue can be attributed on the constant skirmishes between the NPA rebels and the Philippine government in various Lumad communities (Coronel-Ferrer, 2013).

Table 4.

Frequency of Lumad-related Headlines under the Duterte administration

\begin{tabular}{ccc}
\hline Issue (Greed or Grievance) & Frequency & Percentage \\
\hline Violence (Grievance) & 7 & 33.33 \\
Peace talks (Grievance) & 4 & 19.05 \\
NPA Extortion (Greed) & 2 & 9.52 \\
Displacement (Grievance) & 2 & 9.52 \\
Land issues (Greed) & 2 & 9.52 \\
Coffee (Greed) & 1 & 4.76 \\
Martial Law (Grievance) & 1 & 4.76 \\
\hline
\end{tabular}

\section{Discussion}

The study of the political economy of conflict has often been described in terms of inequalities. Divisions between individuals and groups are often pitted against each other in terms of the greed and grievances model on the causes of intrastate war. Despite Collier and Hoeffler's (2004) argument that the causes of most internal conflicts eventually turn from grievances to greed, such assertion provides an oversimplification in understanding the numerous conflicts around the world (Keen, 2000, 2012). Hence, it is necessary to understand that both "greed" and "grievances" are interacting in the evolution of conflicts and there is a need to provide good case studies that will prove it.

As seen in the Lumad struggle, the greed and grievance model provides a logical framework in explaining the causes of conflict in Mindanao. However, one must take caution to conclude that the Lumad struggle in Mindanao will eventually turn into greed in the long run due to compelling statistical tests proving such argument. Drawing mostly from Keen's (2012) interpretation of the greed and grievance model, the following arguments can be inferred in providing an alternative explanation to the causes and evolution of the Lumad conflict.

First, based on the qualitative data, the Lumad struggle proves to be a promising case study in analyzing the evolution of intrastate conflicts. It is evident that the history of the conflict itself is a product of encroachment by outsiders to ancestral lands of the non-Moro indigenous people in Mindanao. For instance, Rodil (1993) argues that systemic oppression of the arrival of Western colonizers and Christian migrants in Mindanao such as the creation of new land laws and the deprivation of the indigenous people to exploit the resources found in their ancestral lands have legitimized the grievances of the Lumad. Thus, it is hard to separate the Lumads aspirations to finally claim their lost lands from the Christian settlers who have pillaged and exploited their land.

Second, it is also important to note that despite the conventional notion that economic greed is fuelled by insurgents wanting to gain economic benefits in the duration of conflict, the "greed" discourse has the effect of delegitimizing various forms of grievances from the insurgents such as protests and social movements (Duffield, 2001). Keen $(2000,2012)$ observes that since the "greed" discourse provides a powerful argument in explaining conflicts, then it seems that there is no more room to listen to the grievances of rebel groups, hence, providing a dangerous premise that all conflicts are economic in nature. Apparently, this is not the case of the Lumad conflict in Mindanao. Throughout its long history, various Lumad groups have asserted their ethnic and political grievances not only through violent means but also through protests and other forms of social platforms such as the lakbayan movements where Lumad leaders travel to Manila to protest their grievances to the Philippine government (Paluga \& Ragragio, 2016).

Third, the economic greed discourse takes away the focus away from abusive states (Keen, 2012). The Philippines provides a good example of an abusive state against the Lumad minorities in Mindanao. As mentioned by Alamon (2017), the Philippine government is backing extractive business interests in Mindanao through the exploitation of natural resources in Lumad lands such as mining and logging activities through the deployment of paramilitary forces. These armed groups do not distinguish Lumad rebels and unarmed civilians, causing a killing spree in the remote areas where most Lumad communities are situated (Paluga \& Ragragio, 2016). Hence, the 
Philippine government here acts as an abusive state that supports business interests at the expense of the Lumads who are fighting for their rights to ancestral domain (Simbulan, 2016).

Abusive states like the Philippines create counter-insurgency movements that fuel more grievances for rebels to resort to violence. Paluga and Ragragio (2016) have mentioned the abuses committed by state forces such as the Armed Forces of the Philippines in displacing the Lumads in their own ancestral domain through intimidation, forced evacuation (bakwit system) and state-sponsored killings to Lumad leaders who oppose military intervention. Corollary, Brown (2008) has observed that ethnic inequalities in Aceh, southern Thailand and the Mindanao conflict in the Philippines have fuelled more grievances when government forces launched counterinsurgency movements to pacify the separatist rebellions. In the case of the Mindanao conflict, the Philippine government has conducted several counterinsurgency campaigns in Lumad communities such as Oplan Bantay Laya I and II under the Arroyo administration and the Oplan Bayanihan under the Aquino administration that sought to end the armed rebellions in Mindanao through military means (Paluga \& Ragragio, 2016). These counterinsurgency operations has forced the Lumads to be displaced in their own communities under the bakwit system (evacuation system), causing them the resort to violent means such as the pangayaw form of warfare against the military forces of the government.

As with most qualitative studies, the results generated from the study are still subject to the following limitations. The first one is the lack of previous studies that detail the Lumad struggle using the greed and grievance model. Despite several attempts by Coronel-Ferrer (2013), Paredes (2015) and Alamon (2017) to explain the state of the Lumads in Mindanao, most methods employed in their studies have focused on the normative explanations but have overlooked the empirical and theoretical implications of their previous studies.

The second limitation concerns the usage of news headlines in interpreting the Lumad struggle. The usage of newspaper headlines should not be interpreted as final descriptions of the Lumads' struggle due to the fact that these discursive theme are based on the application of greed and grievance model in providing a preliminary explanation to the ongoing struggle. Hence, for future studies, there is a need to elaborate the greed and grievance model using other qualitative methods such as ethnographic research or interviews with the Lumads themselves.

\section{Conclusion}

In the Mindanao conflict, are vertical or horizontal inequalities, or a combination of both, causing the Lumad struggle to endure? Based on the initial results of the study, we argue that a combination of both greed and grievance as manifested in the interaction of both ethnic and economic inequalities are causing the Lumad struggle to prolong within the larger Mindanao conflict. Using these two primary discourses in explaining intrastate wars emphasizes that some conflicts tend to endure due to a combination of factors such as the interaction of state and non-state armed groups. As manifested in the Lumad struggle, the interaction of several political and economic causes aggravates the conditions of conflict, such as the Philippine government initiating counter-insurgency programs, Moro armed groups who regard the Lumads as second-class citizens, business interests who exploit resource-rich lands and the Lumad tribes themselves, who suffer the most through systemic discrimination and oppression from the actors mentioned earlier. Furthermore, the interaction of ethnic grievances and economic are manifested in notable events such as the ongoing peace process between the Philippine government and the MILF where Lumad interests are sidelined in the future of a peaceful Mindanao.

Generally speaking, the contributions of this study are twofold. For one, the greed and grievances model have yet to be tested in conflicts beyond sub-Saharan Africa and Latin America in which this study attempts to explain the causes of conflict in the Lumad struggle in Mindanao. Second, the study provides practical and scholarly relevance since there is a seeming gap detailing the literature of the Lumad struggle in the Philippines, this allows us to develop better explanations in understanding the causes and evolution of the conflict in Mindanao.

In conclusion, the study provides two issues for further studies in the Lumad struggle. One is the development of a more sophisticated model that will fully explain conflicts with interacting causes. Finally, there is a need for more qualitative approach that will detail other conflicts in the Philippines as a conflict between greed and grievances. Only then can we fully understand the nature and evolution of intrastate wars in the future.

\section{Acknowledgements}

This article is based on the qualitative data drawn from the author's earlier draft on his graduate seminar on research methods in political science (Political Science 299). I would like to thank Rogelio Alicor Panao and Carolina Hernandez at the Department of Political Science, University of the Philippines for their support in the making of this article. I also thank Sedfrey Candelaria from the Ateneo de Manila University for his insights on the study. I also express my utmost gratitude to Myfel Pauluga and Andrea Malaya Ragragio from Leiden University for allowing me to cite their works on the Lumad struggle. Finally, I thank Teresa Lorena Jopson from the Australian National University for her invaluable support. 


\section{Biographical Note}

Jose Mikhail Perez is a graduate student of international studies at the Department of Political Science, University of the Philippines Diliman, the Philippines.

\section{References}

Alamon, A. (2017). Wars on extinction: Discrimination and the Lumad struggle in Mindanao. Iligan City, Philippines: Mindanao Interfaith Institute on Lumad Studies.

Brown, G. (2008). Horizontal inequalities and separatism in Southeast Asia: A comparative perspective. In F. Stewart (Ed.), Horizontal inequalities and conflict (pp. 252-281). London, UK: Palgrave MacMillan.

Collier, P. (2000). Doing well out of war: An economic perspective. In M. Berdal \& D. Malone (Eds.), Greed and grievance: Economic agendas in civil wars (pp. 91-111). Boulder, CO: Lynne Rienner Publishers.

Collier, P. (2007). The conflict trap. In P. Collier (Ed.), The bottom billion: Why the poorest countries are failing and what can be done about it. (pp.17-37). Oxford, United Kingdom: Oxford University Press.

Collier, P., \& Hoeffler, A. (2004). Greed and grievance in civil war. Oxford Economic Papers, 56(1), 563-595.

Coronel-Ferrer, M. (2012). To share or divide power? Minorities in autonomous regions, the case of the autonomous region in Muslim Mindanao. Ethnic and Racial Studies, 35(12), 2097-2115.

Coronel-Ferrer, M. (2013). Costly wars, elusive peace. Diliman, Quezon City: University of the Philippines Press.

Duffield, M. (2001). Global governance and news: The merging of development and security. London UK: Zed Books.

Fairclough, N., \& Wodak, R. (1997). Critical Discourse Analysis. In T. A. van Dijk (Ed.), Discourse as social interaction (pp. 258-284). London, United Kingdom: SAGE Publications.

Fearon, J. (2004). Why do some civil wars last so much longer than others? Journal of Peace Research, 41(3), 275301.

Fearon, J., \& Laitin, D. (2003). Ethnicity, insurgency and civil war. American Political Science Review, 97(1), 75-90.

Griffen, A. J. (2018). Enacting African American Legislative Voice: A Program Design for the Recruitment and Development of African American Educational Lobbyists. American Journal of Qualitative Research, 2(2), 74-102.

James, G. (2018). A narrative inquiry perspective into coping mechanisms of international postgraduate students' transition experiences. American Journal of Qualitative Research, 2(1), 41-56.

Hoeffler, A. (2011). 'Greed' vs. 'grievance': A useful conceptual distinction in the study of civil war? Studies in Ethnicity and Nationalism, 11(2), 274-284.

Keen, D. (2000). Incentives and disincentives for violence. In M. Berdal \& D. Malone (Eds.), Greed and grievance: Economic agendas in civil wars (pp. 19-43). Boulder, CO: Lynne Rienner Publishers.

Keen, D. (2012). Greed and grievance in civil war. International Affairs (Royal Institute of International Affairs 1944), 4(1), pp. 757-777.

Lara, F. J., \& Champlain, P. (2010). Inclusive peace in Mindanao: Revisiting the dynamics of conflict and exclusion. International Alert, pp. 4-24. Retrieved from https://www.internationalalert.org/sites/default/files/publications/ Inclusive_Peace_in_Muslim_Mindanao_Revisiting_the_dynamics_of_conflict_and_exclusion.pdf

Majul, C. (1973). Muslims in the Philippines. Diliman, Quezon City: University of the Philippines Press.

Øsby, G. (2008). Inequalities, the political environment and civil conflict: Evidence from 55 developing countries. In F. Stewart (Ed.), Horizontal inequalities and conflict (pp. 136-159). London, UK: Palgrave MacMillan.

Paredes, O. T. (2013). A Mountain of difference: The Lumad in early Colonial Mindanao. Ithaca, NY: Cornell University Press.

Paredes, O. T. (2015). Indigenous vs. native: Negotiating the place of Lumads in the Bangsamoro homeland. Asian Ethnicity, 16(2), 166-185.

Quimpo, N. G. (2001). Options in the pursuit of a just, comprehensive, and stable Peace in Southern Philippines. Asian Survey, 41(2), 271-289.

Reynal-Querol, M. (2002). Ethnicity, political systems and civil wars. Journal of Conflict Resolution, 46(1), 29-54.

Rodil, R. (1993). The Lumad and Moro of Mindanao. London, UK: Minority Rights Group.

Ross, M. (Winter 2004). How do natural resources influence civil war? Evidence from thirteen cases. International Organization, 58(1), 35-67.

Stewart, F. (2000). Crisis prevention: Tackling horizontal inequalities. Oxford Development Studies, 28(3), 245-260.

Stewart, F. (2005). Horizontal inequalities: A Neglected Dimension of Development. In Studies in development economics and policy (pp. 101-135). London, UK: Palgrave MacMillan. 
Tebteba Foundation. (2011). Understanding the Lumad: A closer look at a misunderstood culture. Baguio City, Philippines: Valley Printing.

Wadi, J. (2008). Multiple colonialism in Moroland. In B. Tuazon (Ed.), The Moro reader: History and contemporary struggles of the Bangsamoro people (pp. 28-36). Quezon City, Philippines: CenPEG Books.

Wallensteen, P. (2015). Understanding conflict resolution. London, UK: Sage Publications.

Aspinall, E. (2007, December). The construction of grievance: Natural resources and identity in a separatist conflict. Journal of Conflict Resolution, 51(6), 950-972.

Dizon, M. (2014, June). A mountain of difference: The Lumad in early colonial Mindanao by Oona Paredes (A Review). Philippine Studies: Historical and Ethnographic Viewpoints, 62(2), 293-296.

Simbulan, R. (2016, February 16). Indigenous communities' resistance to corporate Mining in the Philippines. Peace Review: A Journal of Social Justice, 28(1), 29-37.

Paluga, M., \& Ragragio, A. (2016, August). Why do indigenous communities resort to voluntary evacuations? A paper presented to the International Conference for People's Rights, Davao City, Philippines, 23-24 July 2016.

Ray, D., \& Esteban, J. (2017, April 28). "Conflict and development." Annual Review of Economics, 9(1), 263-293.

Uppsala Conflict Data Program. (2019, May). UCDP Conflict Encyclopedia. Retrieved from www.ucdp.uu.se

Yigit, I. H. (2018). Mass Religious Ritual and Intergroup Tolerance: The Muslim Pilgrims' Paradox. [Book Review]. Journal of Ethnic and Cultural Studies, 5(2), 196-200. 